\title{
Antifouling efficacy of a controlled depletion paint formulation with acetophenone
}

\author{
Sangmok Jung ${ }^{1}$, Mohandoss Sidharthan ${ }^{1}$, Jihyun Lee ${ }^{2}$, Hanjoo Lee ${ }^{1}$, Jiyoung Jeon ${ }^{1}$, Taehee \\ Park ${ }^{1}$, Junghyun Yoon ${ }^{1}$, Jaehyuk Jeon ${ }^{3}$, Hyunwoung Shin ${ }^{1}$ \\ ${ }^{1}$ Department of Life Science and Biotechnology, Soonchunhyang University, Asan, Chungcheongnam-do, 336-745 South Korea. \\ (SJ) E-mail: thinkdi@gmail.com. ORCID-iD: http://orcid.org/0000-0003-1703-1746 \\ (MS) E-mail: mohansiddhu @ gmail.com. ORCID-iD: http://orcid.org/0000-0001-6631-107X \\ (HL) E-mail: sol332@nate.com. ORCID-iD: http://orcid.org/0000-0002-0379-1907 \\ (JJ) E-mail: znzl6268@naver.com. ORCID-iD: http://orcid.org/0000-0002-7132-7620 \\ (TP) E-mail: bph253@ naver.com. ORCID-iD: http://orcid.org/0000-0002-0834-5885 \\ (JY) E-mail: y6314444@ hanmail.net. ORCID-iD: http://orcid.org/0000-0001-7919-5637 \\ (HS) (Corresponding autor) E-mail: hwshin@sch.ac.kr. ORCID-iD: http://orcid.org/0000-0003-0581-3679 \\ ${ }^{2}$ Korea Fisheries Resources Agency East Sea Branch, 28, Yongheung-ro, Buk-gu, Pohang, Gyungsangbuk-do, South Korea. \\ (JL) E-mail: pander27@fira.or.kr. ORCID-iD: http://orcid.org/0000-0002-1359-1562 \\ ${ }^{3}$ Natural Marine Biodiversity Institute of Korea, Seocheon 33662, South Korea. \\ (JJ) E-mail: jaeheug@ nate.com. ORCID-iD: http://orcid.org/0000-0002-9341-6827
}

Summary: Biofouling is an inevitable problem that occurs continually on marine fishing vessels and other small crafts. The nature of the antifouling (AF) coatings used to prevent biofouling on these small vessels is of great environmental concern. Therefore, the efficacy of a non-toxic AF candidate, acetophenone, was evaluated in preliminary laboratory assays using marine bacteria, diatom and Ulva spores. At a low concentration of $100 \mu \mathrm{g} \mathrm{cm}^{-2}$ of acetophenone, spore attachment of a green fouling alga was significantly reduced $(\mathrm{p}<0.01)$. Similarly, $40 \%$ acetophenone coatings significantly inhibited diatom attachment. This new non-toxic AF agent was incorporated into controlled depletion paint (CDP). Fouling coverage (\%), biomass, and fouling resistance (\%) were estimated. On CDP coatings made with acetophenone (40\%), a significant decrease in fouling biomass was estimated $(\mathrm{p}<0.01)$.

Keywords: Ulva spores; antifouling; acetophenone; fouling biomass; fouling resistance; controlled depletion paint (CDP).

Eficacia antiincrustante de una formulación de pintura de reducción controlada con acetofenona

Resumen: El biofouling es un problema inevitable que ocurre continuamente en los buques de pesca marina y en las pequeñas embarcaciones. La naturaleza de los recubrimientos antiincrustantes (AF) usados para prevenir el bioincrustado en estos pequeños buques tiene gran preocupación ambiental. Por lo tanto, la eficacia de un candidato AF no tóxico, la acetofenona, se evaluó en ensayos preliminares de laboratorio usando bacterias marinas, diatomeas y esporas de Ulva. A una concentración baja de $100 \mu \mathrm{g} \mathrm{cm}^{-2}$ de acetofenona, la adherencia de esporas de una alga incrustante verde se redujo significativamente $(\mathrm{p}<0.01)$. Del mismo modo, el revestimiento de acetofenona a un nivel del $40 \%$ inhibieró significativamente la adherencia de diatomeas. Además, esta nueva acetofenona AF no tóxica se incorporó a la pintura de reducción controlada (CDP). La cobertura de las incrustaciones (\%), la biomasa y la resistencia a la incrustación (\%) fueron estimadas. En recubrimientos de CDP donde se incorporó la acetofenona $(40 \%)$, se estimó una disminución significativa de la biomasa incrustante $(\mathrm{p}<0.01)$.

Palabras clave: esporas de Ulva; antiincrustante; acetofenona; abordaje biomasa; resistencia a la incrustación; pintura de depleción controlada (CDP).

Citation/Como citar este artículo: Jung S., Sidharthan M., Lee J., Lee H., Jeon J., Park T., Yoon J., Jeon J., Shin H. 2017. Antifouling efficacy of a controlled depletion paint formulation with acetophenone. Sci. Mar. 81(4): 449-456. doi: http:// dx.doi.org/10.3989/scimar.04638.13A

Editor: C. Porte.

Received: March 21, 2017. Accepted: November 13, 2017. Published: November 14, 2017.

Copyright: () 2017 CSIC. This is an open-access article distributed under the terms of the Creative Commons Attribution (CC-by) Spain 3.0 License. 


\section{INTRODUCTION}

Marine biofouling is one of the most important problems faced by marine technologies (Yebra et al. 2004). In the marine environment any solid surface submerged in seawater will become covered by a complex layer consisting of an organic conditioning film and microfouling and macrofouling organisms such as marine bacteria, algae, protozoa, barnacles, mussels and tube worms (Mieszkin et al. 2013, Dobretsov et al. 2013). Macrofoulers such as barnacles, mussels and algae constitute a large source of fouling biomass. These organisms attach to the ship's hull, which increases the friction of the boat in the water. Subsequently, fouling on the hull lowers speed, impairs manoeuvrability and ultimately increases fuel consumption (Karlsson and Eklund 2004), thereby causing additional $\mathrm{CO}_{2}$ emissions and maintenance costs (Schultz et al. 2011). The increase in fuel consumption can be up to $40 \%$ and in an overall voyage costs are as much as $77 \%$ more. In addition to the shipping industry it also affects aqua farming industries (Guardiola et al. 2012).

Several physical, chemical and biological methods for preventing marine biofouling have been tested in the last four decades. To prevent the attachment of fouling organisms, the boat hulls are protected with anticorrosive and antifouling (AF) paints. Earlier forms of AF paints are based on the leakage of toxic substances such as copper, tributyltin (TBT) and Irgarol, which prevent the settlement and growth of marine organisms (Soroldoni et al. 2017). These paints are very effective but they also significantly affect other non-target organisms. Potential harmful effects of AF marine paints containing organotin compounds, copper and Irgarol 1051 on coral reef communities are reported (Owen et al. 2001). Among these, TBT, Irgarol 1051 and diuron were banned in 2008. TBT is an endocrine disruptor due to its induction of imposex (imposition of male sexual organs on females) in mollusc species (Horiguchi et al. 1997). Periodic sediment quality surveys carried out around the world indicate persistence of high copper concentrations in marinas and harbours (Schiff et al. 2007). Dissolved trace metals in measured water columns frequently exceed the levels of concern in marinas because of leaching from ship hulls (Hall et al. 1988).

Most of the AF paint formulations manufactured to replace organotin-based paints contain predominantly copper and toxic organic biocides. At elevated concentrations copper has a capacity to cause reproductive disorders in a variety of aquatic organisms (Adeleye et al. 2016). Therefore, the paint industries have been urged to develop tin-free alternatives with the same economic benefits but without harmful effects on the environment and marine life. The toxic effects of zinc pyrithione (ZPT), which is used as a booster biocide in antifouling paints, are well documented (Karlsson and Eklund 2004). However, ZPT is the most prevalently used organic biocide in paints, owing to its shorter half-life and photodegradation properties (Kim et al. 2015). Environmentally acceptable solutions are still needed to prevent fouling organisms. Natural products could provide alternatives as antifouling agents, but their incorporation into a working AF coating is challenging (Chambers et al. 2011).

In this study, the organic compound acetophenone (AP) was formulated with controlled depletion paint (CDP). As an aromatic ketone, AP occurs naturally in many foods such as apples, cheese, apricots, bananas, beef, cauliflowers and castoreum (Müller-Schwarze and Houlihan 1991). Its derivatives are widely used in the food, perfume, pharmaceutical and polymer industries. To this end, the AF efficiency of AP was screened with the marine bacterium Bacillus macrolides, the diatom Navicula incerta and the macroalgal spore Ulva pertusa. Newly prepared AF coatings were tested in various field conditions using test panels. The AF performance of AP was assessed against fouling organisms of the east coast of Korea.

\section{MATERIALS AND METHODS}

\section{Antibacterial activity}

Antibacterial assays were conducted with the AF candidate $\mathrm{AP}$ and other reference biocides [tributyltin chloride (TBTCl) and ZPT]. A marine bacterium, $B a$ cillus macroides (strain KORDI-13724), was used. Assays were conducted using the paper disc method. Aliquots of test chemicals were loaded onto a paper disc and dried at room temperature for about $12 \mathrm{~h}$. B. macroides culture was raised in marine agar broth (DIFCO, Detroit, MI, USA). At the log phase of growth, it was inoculated onto an agar plate (prepared with marine agar (DIFCO, Detroit, MI, USA) and spread uniformly to make a bacterial lawn. Then experimental paper discs were placed on the bacterial lawn and the agar plates were incubated for $48 \mathrm{~h}$ at $28^{\circ} \mathrm{C}$. At the end of the experiments, the inhibition zone formed was measured. Three replicates were used and the results were expressed as mean \pm sd.

\section{Diatom attachment}

A biofilm-forming diatom species, Navicula incerta (KMMCC no. B001), was used for this assay. $N$. incerta cultures were raised in $\mathrm{f} / 2$ medium and during their exponential growth stage diatom cells which settled down at the bottom of the flask were carefully collected without disturbing the attached cells. Then the culture was repeatedly washed with sterile seawater $(0.45 \mu \mathrm{m}$ filtered) to obtain a cell suspension with single cells. The initial cell density was measured using an improved Neubauer haemocytometer (Paul Marienfeld, GmbH and Co., KG, Germany) and was then adjusted to $1.0 \times 10^{5} \mathrm{ml}^{-1}$ using sterile seawater. Standard microscopic slides $(7.5 \times 2.5 \mathrm{~cm})$ were brush-coated with about $0.5 \mathrm{~mL}$ of experimental coatings (AP-CDP 10-40\%, AP and ZPT 10:3 and 20:3 levels and acidwashed glass slides served as control). These slides were subjected to a diatom assay by the method given elsewhere (Pettitt et al. 2004), with a slight modification of microscopic cell enumeration. Attached cells were carefully removed into $1 \mathrm{~mL}$ of sterile seawater and 
the number of cells was examined under a microscope. The cells were counted in 20 random fields of view (Muthukrishnan et al. 2017). Results are expressed as diatom cells attached per $\mathrm{mm}^{2}$ of experimental coating surface.

\section{Ulva spore attachment and germination}

Spore attachment and germination experiments were conducted in 24 well plates (Corning Co. USA) coated with different concentrations of AF candidates [dissolved in methanol $(\mathrm{MeOH})]$, as outlined by Hattori and Shizuri (1996). Ulva pertusa samples were collected from the west coast of the Republic of Korea. In the laboratory, debris and epiphytes were removed by washing twice in seawater $(0.45 \mu \mathrm{m}$ filtered $)$. Spore release was facilitated after a desiccation treatment (Fletcher 1989). Initial spore density was determined using a hemocytometer under a light microscope (Olympus CK2, Japan). Spore density in the inoculation suspension was adjusted to $2 \times 10^{5} \mathrm{ml}^{-1}$ by addition of seawater $(0.45 \mu \mathrm{m}$ filtered). In each coated well, 1 $\mathrm{mL}$ of spore suspension containing $2 \times 10^{5}$ spores was inoculated along with $1 \mathrm{ml}$ of filtered seawater and 10 $\mu \mathrm{l}$ of ampicillin $\left(100 \mathrm{mg} \mathrm{l}^{-1}\right)$. Well plates were then incubated in a darkroom for $6 \mathrm{~h}$. Thereafter, the spore suspension in the well plate was discarded and the wells were gently washed twice with sterile seawater $(0.45 \mu \mathrm{m})$ to remove the loosely attached or unattached spores. Spore attachment was examined under microscope $(200 \times)$. Six microscopic fields were counted per well along the central region. Later, the wells were refilled with two mL of Provasoli's Enriched Seawater medium and the well plates were incubated in a growth chamber under continuous light $\left(60 \mu \mathrm{mol} \mathrm{m} \mathrm{m}^{-2} \mathrm{~s}^{-1}\right)$. Five days later, the culture medium was pipetted out from each well and successfully germinated spores were counted in 20 fields of view under microscope $(200 \times)$ (Muthukrishnan et al. 2017). Results were expressed as a mean number of spore $\mathrm{mm}^{-2}$.

\section{Formulation of CDP and coating}

In the preparation of CDP formulations, vinyl resin (DOW Co., South Korea), wood rosin, AP (2',4' -dihydroxyacetophenone, Acros chemical Co., USA), AP (1-Hydroxypyridine-2-thione zinc salt, Acros chemical Co., USA) and TBTCl (Sigma-Aldrich Co., USA), methyl isobutyl ketone (MIBK) and methyl ethyl ketone (Samchun Co., South Korea) and other pigments and additives (industrial grade) were used.

In order to evaluate the performance of AP in field conditions, typical CDP formulations were made using MIL-P-15931B formula 121/63 (D3623-78a: ASTM 2004), and are given in Tables 1 and 2 . Using the above formulation, the AP- and TBT-CDPs were prepared. The TBT-CDP was used as a positive control. The required quantity of xylene and MIBK was taken in a container and homogenized with the help of a highdispersion mechanical stirrer. An absorbent (zeolite) was added, followed by a dispersant, and it was stirred well to get a homogenous mixture. Rosin and vinyl
Table 1. - Formulations of controlled depletion paints with acetophenone and zinc pyrithione. Based on ASTM standard formula (Mil-p-15931B, 121/63) (D3623-a: ASTM 2004). AF agent, acetophenone; booster biocide, zinc pyrithione; MIBK, methyl isobutyl ketone.

\begin{tabular}{lcccccccc}
\hline \multirow{2}{*}{ Recipe } & \multicolumn{4}{c}{ Acetophenone $(\%)$} & \multicolumn{5}{c}{ Acetophenone: } \\
& 10 & 20 & 30 & 40 & $10: 3$ & $20: 3$ & $30: 3$ & $40: 3$ \\
\hline AF agent & 10 & 20 & 30 & 40 & 10 & 20 & 30 & 40 \\
Booster biocide & - & - & - & - & 3 & 3 & 3 & 3 \\
Vinyl resin & 5 & 6 & 6 & 6 & 5 & 6 & 6 & 6 \\
Wood rosin & 8 & 8 & 8 & 8 & 8 & 8 & 8 & 8 \\
Iron oxide & 9 & 6 & 5 & 5 & 9 & 6 & 5 & 5 \\
Zinc oxide & 20 & 14 & 12 & 9 & 17 & 11 & 9 & 6 \\
Thickener & 2 & 2 & 1 & 1 & 2 & 2 & 1 & 1 \\
Anti-settling agent & 5 & 3 & 3 & 1 & 5 & 3 & 3 & 1 \\
Dispersant & 1 & 1 & 1 & 1 & 1 & 1 & 1 & 1 \\
Tricresyl phosphate & 7 & 5 & 4 & 4 & 7 & 5 & 4 & 4 \\
Absorbent & 2 & 4 & 1 & 1 & 2 & 4 & 1 & 1 \\
Xylene & 23 & 23 & 21 & 18 & 23 & 23 & 21 & 18 \\
MIBK & 8 & 8 & 8 & 6 & 8 & 8 & 8 & 6 \\
Total & 100 & 100 & 100 & 100 & 100 & 100 & 100 & 100 \\
\hline
\end{tabular}

Table 2. - Formulations of controlled depletion paints with tributyltin chloride (TBT) and zinc pyrithione (ZPT) based on ASTM standard formula (MIL-P-15931B, 121/63) (ASTM 2004). AF agent, TBTCl; booster biocide, ZPT; MIBK, methyl isobutyl ketone.

\begin{tabular}{lcc}
\hline Recipe & TBT & TBT:ZPT \\
& $30(\%)$ & $30: 3(\%)$ \\
\hline AF agent & 30 & 30 \\
Booster biocide & - & 3 \\
Vinyl resin & 6 & 6 \\
Wood rosin & 8 & 8 \\
Iron oxide & 5 & 5 \\
Zinc oxide & 12 & 9 \\
Thickener & 1 & 1 \\
Anti-settling agent & 3 & 3 \\
Dispersant & 1 & 1 \\
Tricresyl phosphate & 4 & 4 \\
Absorbent & 1 & 1 \\
Xylene & 21 & 21 \\
MIBK & 8 & 8 \\
Total & 100 & 100 \\
\hline
\end{tabular}

resin binders were added and the mixture was again stirred for 20 to $40 \mathrm{~min}$. The other ingredients, AF agent, pigment, iron oxide (extender) and zinc oxide (anticorrosive), were added and stirred well (1300 rpm) for 20 minutes. Finally, a booster biocide, a plasticizer, an anti-settling agent and other additives were added and the mixture was stirred well for 20 minutes. The homogeneous mixture was transferred to a glass bead mill to obtain a fine dispersion (Motor mill, Hwa Sung Industrial CO., Korea). Particle size was fixed at 50 $\mu \mathrm{m}$. The fineness and viscosity of the prepared paint were determined by a Hegman-type gauge and a Ford cup (\#3, \#4 and \#5), respectively. For comparison, two copper-based commercial AF paints with rosin matrix, Waterways and Cruiser (Future Series, International paint Co., UK), were also used.

\section{Test panel coatings and evaluation}

Test panel studies were conducted with PVC panels $(10 \times 10 \times 0.5 \mathrm{~cm})$. Before coating, the test panel surface was roughened with emery paper (\#1000). The prepared paint was sprayed three times on the panels with a spray gun (W-2000, nozzle size: $1.3 \mathrm{~mm}$, Hyup Sung. 
Co., Korea) with compressed air $(0.7 \mathrm{MPa})$ and a spray distance of $150-200 \mathrm{~mm}$. The wet thickness of the coatings was measured by wet comb gauge (Elcometer 2400 viscosity disc). The coated panels were then air dried at room temperature for 24 hours.

A standard test method of adhesion by knife (D6677-1: ASTM 2001) was determined by making an " $X$ " cut into the coating film to the substrate and by lifting the coating with a knife. Adhesion was evaluated qualitatively on a 0 to 10 scale. The degree of blistering of paint film was evaluated by comparison with the photographic references of standards (D714-87: ASTM 2000). The fineness of dispersion of the pigment-vehicle system was evaluated using a single-path Hegman-type gauge (D1210-96: ASTM 1988). The prepared CDP was spread by a scraper on a machinetapered path. At some point in this path, particles or agglomerates, or both, became visible. A direct reading from the graduated scale was then made at the point where the particles formed a definite pattern.

\section{Field experiments}

The coated panels were tied in a random order to PVC frames with nylon ties. The prepared panel setup was immersed in Ayajin harbour at a minimum depth level of $0.3 \mathrm{~m}$ for 3 months. After being exposed to Ayajin harbour waters, test panel sets were taken out and digital images of every individual panel were recorded with a five-megapixel camera (C-4000, Olympus, Japan). For the purpose of identification and quantification, a 25 -square mesh $(10 \times 10 \mathrm{~cm})$ was used to examine the fouling assemblages. Each small square was equal to $4 \%$ of the whole mesh. Later, from every individual panel, fouling assemblage on a section of area was scraped and preserved in $4 \%$ formalin. In the laboratory, both digital images and preserved samples were analysed. From digital images and microscopic observations, micro- and macroscopic algae and animals were identified (Meinkoth 1990). Their fouling coverage and biomass were also determined as per ASTM (2004). For data analysis, comparison between means of control and treatment was performed using SPSS 10.0. A one-way ANOVA was carried out to find significant differences at $\mathrm{p}<0.05$ or $\mathrm{p}<0.01$.

\section{RESULTS}

The viscosity and fineness of dispersion of prepared CDP formulations were found to be consistent with the spray coatings (Table 3 ). Moderate viscosity levels were obtained for AP-CDPs (Ford cup \#4: <132 cSt) except the AP:ZPT (10:3) formulation, whereas commercial coatings (copper-based Waterways and Cruiser) exhibited high viscosities (Ford cup \#4: 112$122 \mathrm{cSt}$ ). A fine dispersion of $40 \mu \mathrm{m}$ was achieved for all the AP-CDP combinations. The physicochemical properties of prepared CDP coatings-adhesion, hardness, appearance of surface blister and wettability determined as per standard ASTM methods_-are given in Table 4. The AP-CDP formulations exhibited moderate physical properties when compared with commercial
Table 3. - Viscosity (cSt) and dispersion ( $\mu \mathrm{m})$ of prepared AP-CDP formulations a Fineness of dispersion by Hegman gauge; AP, acetophenone; ZPT, zinc pyrithione; TBT, tributyltin chloride; Comm., commercial formulations ( ${ }^{\mathrm{b}}$ and ${ }^{\mathrm{c}}$, Copper-based Future series, International paint Co., Ltd.); ${ }^{d}$, viscosity (cSt) of oil standards at $25^{\circ} \mathrm{C}$.

\begin{tabular}{llcccc}
\hline \multirow{2}{*}{ Groups } & CDP & \multicolumn{3}{c}{ Ford cup (Viscosity cSt) } & Dispersion a \\
& formulation & $\# 3$ & $\# 4$ & $\# 5$ & $(\mu \mathrm{m})$ \\
\hline AP & $10 \%$ & 80 & 122 & 472 & 40 \\
& $20 \%$ & 68 & 106 & 411 & 40 \\
& $30 \%$ & 59 & 92 & 363 & 40 \\
& $40 \%$ & 47 & 75 & 303 & 40 \\
AP:ZPT & $10: 3 \%$ & 86 & 132 & 508 & 40 \\
& $20: 3 \%$ & 63 & 99 & 387 & 40 \\
& $30: 3 \%$ & 56 & 89 & 351 & 40 \\
& $40: 3 \%$ & 43 & 69 & 278 & 40 \\
TBT:ZPT & $30: 0 \%$ & 43 & 69 & 278 & 40 \\
& $30: 3 \%$ & 68 & 106 & 411 & 40 \\
Comm. & Waterways ${ }^{b}$ & 73 & 112 & 436 & 80 \\
& Cruiser & 80 & 122 & 472 & 80 \\
Con & control paint & 84 & 129 & 496 & 40 \\
Std & Oil standard & $49-220$ & $70-370$ & $200-1200$ & \\
& & $(120)^{\mathrm{d}}$ & $(120)^{\mathrm{d}}$ & $(460)^{\mathrm{d}}$ & \\
\hline
\end{tabular}

Table 4. - Physical properties of prepared CDP coatings. AP, acetophenone; ZPT, zinc pyrithione; TBT, tributyltin chloride; Comm.: commercial formulations (Copper-based Future series, International paint Co., Ltd.). Surface blisters: F, few; M, medium; MD, medium dense; D, dense. Wettability: G, Goo. Adhesion: strength of adhesion is indicated in a $0-10$ point scale.

\begin{tabular}{llcccc}
\hline Groups & $\begin{array}{l}\text { CDP } \\
\text { Coating }\end{array}$ & Adhesion & Hardness & $\begin{array}{c}\text { Surface } \\
\text { blister }\end{array}$ & $\begin{array}{c}\text { Wettabil- } \\
\text { ity }\end{array}$ \\
\hline AP & $10 \%$ & 2 & 0.165 & $\mathrm{M}$ & $\mathrm{G}$ \\
& $20 \%$ & 2 & 0.128 & $\mathrm{~F}$ & $\mathrm{G}$ \\
& $30 \%$ & 2 & 0.109 & $\mathrm{~F}$ & $\mathrm{G}$ \\
AP:ZPT & $40 \%$ & 4 & 0.081 & $\mathrm{~F}$ & $\mathrm{G}$ \\
& $10: 3 \%$ & 4 & 0.151 & $\mathrm{M}$ & $\mathrm{G}$ \\
& $20: 3 \%$ & 2 & 0.156 & $\mathrm{M}$ & $\mathrm{G}$ \\
TBT:ZPT & $30: 3 \%$ & 4 & 0.065 & $\mathrm{~F}$ & $\mathrm{G}$ \\
& $40: 3 \%$ & 2 & 0.118 & $\mathrm{~F}$ & $\mathrm{G}$ \\
Comm. & $30: 0 \%$ & 4 & 0.003 & $\mathrm{M}$ & $\mathrm{G}$ \\
& Waterways & 2 & 0.009 & $\mathrm{D}$ & $\mathrm{G}$ \\
Con & Cruiser & 2 & 0.332 & $\mathrm{MD}$ & $\mathrm{G}$ \\
& control paint & 2 & 0.491 & $\mathrm{MD}$ & $\mathrm{G}$ \\
\hline
\end{tabular}

AF paints. CDP coatings prepared with TBT (30\%) and TBT:ZPT (30\%:3\%) exhibited low hardness with high surface blisters.

The antibacterial activities of the AF candidate,

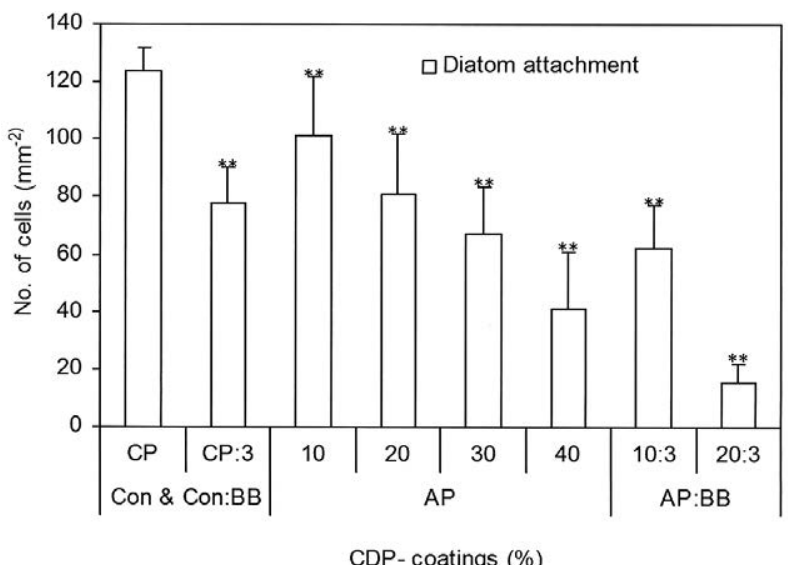

Fig. 1. - Diatom (Navicula incerta) attachment on CDP coatings prepared with acetophenone (AP) and zinc pyrithione (BB). Means are compared with control by one-way ANOVA followed by Dunnett's test $(* \mathrm{p}<0.05 ; * * \mathrm{p}<0.01)$. 
Table 5. - Antibacterial activity of AF agents and booster biocide used in this study against Bacillus macroides (Mean inhibition zone $\mathrm{mm} \pm \mathrm{SD}, \mathrm{n}=3$ ). AP, acetophenone; $\mathrm{ZPT}$, zinc pyrithione; TBT, tributyltin chloride; DMSO, dimethyl sulfoxide.

\begin{tabular}{lccccc}
\hline $\begin{array}{l}\text { Test } \\
\text { chemicals }\end{array}$ & 0 & 50 & 100 & 500 & 1000 \\
\hline Control & 0 & & & & \\
DMSO & 0 & 0 & $1.00 \pm 0.00$ & $2.00 \pm 1.00$ & - \\
AP & 0 & $2.00 \pm 0.05$ & $5.00 \pm 1.00$ & $7.00 \pm 0.50$ & $9.50 \pm 0.50$ \\
ZPT & 0 & $4.00 \pm 1.00$ & $6.50 \pm 1.80$ & $10.00 \pm 1.00$ & $14.00 \pm 2.00$ \\
TBT & 0 & $8.50 \pm 1.00$ & $14.50 \pm 1.32$ & $20.00 \pm 3.00$ & $27.00 \pm 1.32$ \\
\hline
\end{tabular}

Table 6. - Effect of AP on attachment and germination of spores of the fouling alga, Ulva pertusa (means are compared with control by one-way ANOVA followed by Dunnett's test: ${ }^{*} \mathrm{p}<0.05$; $* * \mathrm{p}<0.01$ ). $\mathrm{AP}$, acetophenone; $\mathrm{MeOH}$, methanol; ZPT, zinc pyrithione; TBT, tributyltin chloride; $\mathrm{Cu}$, copper sulfate.

\begin{tabular}{lrrr}
\hline Test chemicals & $\begin{array}{c}\text { Conc. } \\
\left(\mu \mathrm{g} \mathrm{cm}^{-2}\right)\end{array}$ & $\begin{array}{c}\text { No. of Ulva pertusa spores } \mathrm{mm}^{-2} \\
\text { Attached }\end{array}$ & \begin{tabular}{c} 
Germinated \\
\hline Control
\end{tabular} \\
MeOH & 50 & $27.70 \pm 4.33$ & $20.65 \pm 6.05$ \\
AP & 50 & $25.30 \pm 5.59$ & $17.75 \pm 5.48$ \\
AP & 100 & $21.85 \pm 5.20$ & $18.65 \pm 6.33$ \\
AP & 250 & $13.90 \pm 3.75^{* *}$ & $14.20 \pm 6.70^{* *}$ \\
AP & 500 & $11.25 \pm 4.04^{* *}$ & $7.95 \pm 5.41^{* *}$ \\
AP & 1000 & $8.20 \pm 1.85^{* *}$ & $4.30 \pm 2.57^{* *}$ \\
ZPT & 100 & $9.50 \pm 3.19^{* *}$ & $4.05 \pm 1.96^{* *}$ \\
TBT & 100 & $9.20 \pm 2.61^{* *}$ & $5.85 \pm 1.57^{* *}$ \\
Cu & 100 & $15.10 \pm 3.97^{* *}$ & $10.75 \pm 3.16^{* *}$ \\
\hline
\end{tabular}

AP, and biocides against the marine biofilm-forming bacterium $B$. macroides are shown in Table 5 . The antibacterial efficiency was found to be in the following order: TBTCl $>\mathrm{ZPT}>\mathrm{AP}>$ control. In all the concentrations tested, a moderate antibacterial activity was observed for AP at $1000 \mu \mathrm{g}$ disc $^{-1}$ with $9.50 \pm 0.50 \mathrm{~mm}$ of inhibition zone, whereas TBTCl (positive control) exhibited the highest inhibitory zones due to its toxic nature. Attachment of the diatom $N$. incerta to CDP coatings made with series of AP and ZPT concentrations is shown in Figure 1. A substantial decrease in diatom attachment was observed on AP (40\%) and a combination of AP:ZPT $(20 \%: 3 \%)$ coatings $(67 \%$ and $87 \%$ of controls, respectively, $\mathrm{p}<0.01)$.

Effects of AP and other biocides on attachment and germination of spores of $U$. pertusa are shown in Table 6. AF activity against Ulva spores increased with increasing concentrations of AP. On experimental AP coatings $\left(1000 \mu \mathrm{g} \mathrm{cm}^{-2}\right)$, a maximum of $70 \%$ and $79 \%$ reduction in Ulva spore attachment and germination were observed, respectively, compared with control. On the other hand, at a low concentration of $100 \mu \mathrm{g}$ $\mathrm{cm}^{-2}$ of toxic biocides such as TBTCl and ZPT, more than a $70 \%$ reduction in Ulva spore germination was observed $(\mathrm{p}<0.01)$. For non-toxic AP coatings at 250 $\mu \mathrm{g} \mathrm{cm}{ }^{-2}$, both spore attachment and germination were significantly reduced to $\leq 50 \%$ levels $(\mathrm{p}<0.01)$.

In the fouling assemblages observed on untreated control panels, six major components were observed: macroalgae (Ulva pertusa, Ectocarpus sp., Ceramium sp., Porphyra tenera and Gelidium sp.), barnacles ( $B a$ lanus sp.), tube worms (Spirobis sp.), sponges (Cliona sp., Halichondria sp.), tunicates (Botrylloides sp.) and microalgal biofilm consisting of diatoms. Based on standard fouling ratings (ASTM 2004), data obtained on antifouling characteristics of different CDP

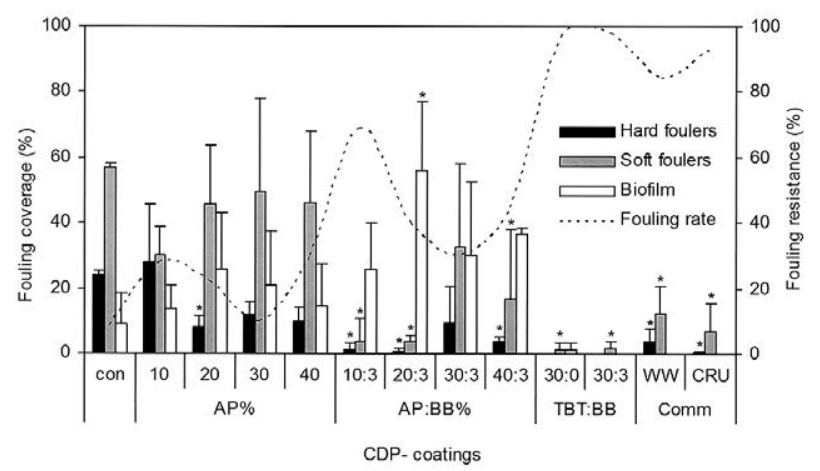

Fig. 2. - Comparison of coverage (\%) of major components of fouling assemblages on CDP-coated panels exposed for three months to waters of Ayajin harbour, South Korea. Means are compared with control by one-way ANOVA followed by Dunnett's test $(* \mathrm{p}<0.05)$.

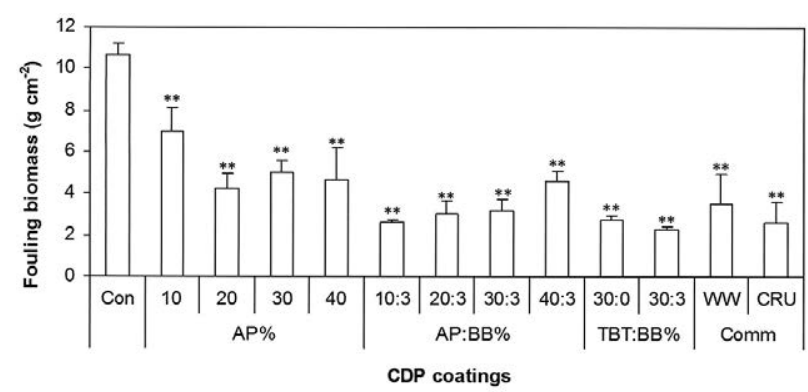

Fig. 3. - Comparison of total fouling biomass estimated on CDPcoated panels exposed for three months to waters of Ayajin harbour, South Korea. Means are compared with control by one-way ANOVA followed by Dunnett's test $(* \mathrm{p}<0.05 ; * * \mathrm{p}<0.01)$.

coatings prepared in this study were assessed. The antifouling properties of AP and AP and ZPT coatings were comparable to the commercial paints, which contain copper (Figs 2 and 3). The order of reduction in fouling coverage $(\%)$ on the experimental panels was found to be TBT $>\mathrm{Cu}>\mathrm{AP}$ and $\mathrm{ZPT}>\mathrm{AP}>$ control. The assessments of fouling coverage of all the experimental panels indicate the predominance of soft foulers. AP- and TBT-CDP coatings prepared in combination with ZPT (the most commonly used booster biocide) effectively inhibit the recruitment of soft foulers (Fig. 2). There was a twofold decrease in coverage of hard foulers in AP-CDP coatings (at 20\% level, $\mathrm{p}<0.05)$, whereas the addition of ZPT $(3 \%)$ further prevented the growth of hard foulers, with a 3-4 fold decrease (AP (20\%):ZPT(3\%), p<0.05), compared with control.

Fouling resistance was determined for the panels coated with AP and AP and ZPT experimental paints according to the ASTM (2004) procedure (Fig. 3). AF performance of prepared AP-CDP formulation increased with increasing concentrations. Similarly, with ZPT booster biocide, the prepared AP-CDP formulations showed higher fouling resistance against fouling organisms of the Ayajin harbour waters. APCDP (10\%-40\%) coatings showed 10\%-30\% fouling resistance against both soft and hard fouling communities. Addition of ZPT (3\%) increased the fouling resistance to a maximum of $69 \%$ (Fig. 2). Very high fouling resistance equal to that of commercial AF paints (Waterways and Cruiser) was observed from TBT and 
TBT-ZPT coatings $(\mathrm{p}<0.05)$, due to their toxic biocidal properties.

The total fouling biomass observed from experimental panels $\left(\mathrm{g} \mathrm{cm}^{-2}\right)$ is shown in Figure 3. On APCDP coatings (10-40\% levels), a 35\%-60\% reduction in fouling biomass was observed $(\mathrm{p}<0.05)$. More than $50 \%$ reduction in fouling biomass buildup was seen in all the AP- and TBT-SPC coatings in which ZPT was used as a booster biocide $(\mathrm{p}<0.05)$. Their AF efficiencies were comparable to the two commercial reference coatings tested.

\section{DISCUSSION}

The new antifouling candidate AP was tested for antimicrobial activity against the marine bacterium $B$. macrolides in this study. As a result, the concentration of AP should increase up to two-fold to achieve the same activity as commercial AF agent ZPT (positive control). Yeast cells maintained $25 \%$ viability when the AP was used at $17 \mathrm{mM}$ (Rogers et al. 1999). Lin et al. (2011) reported that a paper disc assay using AP concentration at $200 \mu \mathrm{g} \mathrm{disc} \mathrm{d}^{-1}$ had antibacterial activity against Staphylococcus epidermidis similar to that of natural products. AF activity against microalgae $N$. incerta increased with increasing concentrations of AP from $10 \%$ to $40 \%$ in paint. In a previous study, the antifouling agent $\mathrm{Cu}_{2} \mathrm{O}$ and TBT were found to be effective at $150 \mu \mathrm{g} \mathrm{ml}^{-1}$ (Hellio et al. 2002). Coatings containing TBT, copper and silicon were evaluated for AF activity against diatom (Cassé and Swain 2006) in static condition, and TBT and copper coatings were not significantly different.

The most common macrofouling algae are species of Enteromorpha, Ulva, Chaetomorpha, and Cladophora (green algae); Ectocarpus (brown algae); and Polysiphonia, Ceramium (red algae) occurring along the coastal regions with high density (Callow 1996). Many of these fouling organisms are opportunistic and able to colonize on a variety of hard substrata in the marine environment. Colonization of these fouling organisms drastically decreases the speed of vessels because of the high frictional resistance (Adkins et al. 1996). The speed loss is proportional to fuel consumption. It is reported that the increased fuel consumption can be $40 \%-70 \%$ of the overall cost of voyage (Champ 2001). The species of Enteromorpha and Ulva are cosmopolitan in distribution and are considered to be one of the dominant shipfouling algae. Biofouling is a site-specific phenomenon in which environmental factors play a decisive role. Especially in harbours, which are enclosed and thus have restricted tidal movement, both algal and animal fouling organisms undergo prolific growth. In the Ayajin harbour, on the east coast of Korea, soft fouling is mainly due to U. pertusa, as this alga grows in high densities. In an AF test panel study conducted from October 2000 to March 2001, U. pertusa occurred on test panels with high fouling coverage (Sidharthan et al. 2004). The very high abundance of $U$. pertusa prevailing on the Korean coast frequently causes green tides. Over the last 10 years, the occurrence of green tide has been recognized as a major environmental problem in Korea (Choi et al. 2001). A seasonal peak with very high biomass $(2.2 \mathrm{~kg}$ fwt. $\mathrm{m}^{2}$ ) of $U$. pertusa was reported from the Korean coast for the month of May (Kim et al. 2004). However, the seasonal variation was found to be less in Ayajin harbour waters as the prevailing high nutrient influx is conducive to the exorbitant growth of $U$. pertusa. It is therefore all the more important to control the recruitment and growth of this monospecific algal fouler. During the present study $U$. pertusa was also found in high densities. The non-toxic AP coatings screened in this study exhibited effective AF activity against $U$. pertusa. The effective concentration from $250 \mu \mathrm{g} \mathrm{cm}^{-1}$ AP affected macroalgae of attachment and germination compared with control and $\mathrm{MeOH}$. However, the AP exhibited two times less AF activity than the commercial agent ZPT.

To know the species involved in biofouling and their assemblage pattern, test panel studies were undertaken. A typical biofouling experiment was conducted by ASTM (2004) with $25 \times 10 \mathrm{~cm}$ coated panels. Similarly, in the present study at Ayajin harbour, South Korea, soft foulers such as macroalgae, sponges and tunicates were found with high fouling coverage.

The CDP type of coatings incorporated with nontoxic AF agents such as sodium benzoate and three different tannins are shown to inhibit the attachment of nauplii of Balanus amphitrite (Stupak et al. 2003). Later, in field trials conducted for 4 months at the Club de Motonautica, Argentina, these AF paints effectively inhibited major fouling organisms such as Balanus amphitrite, Polydora ligni, Enteromorpha and Ectocarpus. In view of known environmental fate and cost-effectiveness, these types of non-toxic organic chemicals are recognized as an alternative to inorganic and toxic AF chemicals. In the present attempt such an AF CDP coating formulated with AP was found to effectively prevent hard and soft foulers compared with controls in Ayajin harbour along the east coast of Korea.

AF paints are complex materials with regard to the large number of compounds introduced in their formulation. The optimization of the protective activity of paints is an economic and ecological challenge which requires the understanding of the precise function of each compound (Thouvenin et al. 2002). The paint forms a single layer on the substrate, which has antifouling chemical attributes. Though it is a chemical, it is not toxic. Additives are important to preserve the physical and chemical properties of paints.

Soluble matrix types of paint have been developed in order to avoid the loss of AF efficiency with time by incorporating a binder (rosin) which dissolves slowly in seawater. These kinds of paint contain high proportions of rosin, which occurs naturally from the exudation of pine and fir trees (Rascio et al. 1988). Rosin may not prevent seawater from penetrating into the polymer matrix through hydrophobic interactions (Yebra et al. 2004). In the resulting, leached layer was $>50 \mu \mathrm{m}$ in thickness due to the continuous dissolution of the copper(I) oxide pigments (Yebra et al. 2004). However, the main drawback of rosin-based coating is 
that erosion of the paints increases with increasing vessel speed (Anderson and Hunter 2000).

Since 1986, the traditional antifouling coatings have been modified with reinforcing resins and are now generally referred to as CDP. To improve the physical properties, plasticizers are used as desiccants and dispersants (Chung 1994). In the present study, wood rosin used in CDP formulation with AP served as a soluble matrix in order to increase the polishing rate of coating.

High rosin content with a co-binder and plasticizer can give good mechanical properties (Rascio et al. 1990). On the other hand, addition of vinyl resin used at optimum levels tends to control the rapid solubilization of the rosin-based matrix and prevent excessive release of the incorporated AF agent and biocides (Lejars et al. 2012).

A smooth paint surface without extensive fouling (i.e. macrofouling and thick slimes) is necessary to avoid friction during sailing. The modelling of AF systems is based on different physical and chemical reaction mechanisms.

Coating technology is fundamentally dependent upon good adhesion between the coating and the substrate, and in many cases adhesion is the limiting factor for the wider application of the technology (AldrichSmith et al. 2005). A phenomenon peculiar to painted surfaces is the formation of blisters which can weaken the coatings. A test method called D714-87 (ASTM 2004) describes the size and density of the blister so that comparisons of severity can be made. In the present study, compared with moderately dense blisters on commercial coatings ( $\mathrm{Cu}$ based), few blisters were observed on the new CDP coatings containing AP.

An ideal paint film thickness can only be achieved if the coating has even upper and lower surfaces and a defined density. In practice, neither the surface of the coating nor that of the substrate is even. The influence of surface irregularities and density on the results of each coating is well documented. Film thickness of CDP coatings made with AP ranged from 70 to 286 $\mu \mathrm{m}$. The film thickness of the coatings can be increased further to give a desired leaching rate with a better coating life.

In a previous study conducted in Ayajin harbour with a seaweed-based (Ishige okamurae) soluble matrix type of AF coating, over an $80 \%$ decrease in coverage of a macrofouling alga, Ulva pertusa, is reported. Non-toxic hybrid CDP coatings prepared with ethyl heptanoate (10-40\%) in acrylic resin matrix showed more than $75 \%$ fouling resistance for four months in Ayajin harbour waters (Sidharthan et al. 2006). Test panels of these hybrid CDP coatings in combination with $4-12 \%$ of ZPT provided more than $60 \%$ fouling resistance over a period of one year. Similarly, APCDP coatings were effective against $U$. pertusa and the addition of a co-biocide, ZPT, at 3\% substantially reduced the recruitment of hard foulers on test panels exposed to Ayajin harbour waters.

These studies clearly indicate the importance of compatibility of binders with AF agents and biocides in formulating coatings with better leaching properties.
Similar observations were seen in AP-CDP coating $(10 \%)$ in which comparatively less fouling coverage was observed, which may be due to insufficient concentration of AP leached in the coating-seawater interface. As suggested by Del Amo et al. (1989), with proper designing of the CDP-matrix using compatible co-binders, plasticizers and pigments, a much improved leaching effect can be achieved.

Independent laboratory bioassays carried out in this study with micro- and macrofouling organisms revealed the AF potential of AP. In particular, the results showed effective control of a fouling alga, U. pertusa, by AP incorporated in CDP coatings. In combination with AP, the new AF formulation effectively prevented both algal and animal macrofoulers. The performance of these AF coatings can be comparable to toxic copper- and TBT-based coatings. However, further studies are needed to reveal the AF mechanism of AP in order to use it more effectively in environmentally acceptable AF coatings.

\section{ACKNOWLEDGEMENTS}

This study was supported by Soonchunhyang University.

\section{REFERENCES}

Adeleye A.S., Oranu E.A., Tao M., et al. 2016. Release and detection of nanosized copper from a commercial antifouling paint. Water Res. 102: 374-382.

https://doi.org/10.1016/j.watres.2016.06.056

Adkins J.D., Mera A.E., Roe-short M.A., et al. 1996. Novel nontoxic coatings designed to resist marine fouling. Prog. Org. Coat. 29: 1-5. https://doi.org/10.1016/S0300-9440(96)00646-7

Aldrich-Smith G., Jennett N., Housden J. 2005. Adhesion of thin coatings - the VAMAS (TWA 22-2) interlaboratory excercise. Surf. Coat. Tech. 197: 336-344. https://doi.org/10.1016/j.surfcoat.2004.07.113

Anderson C.D., Hunter J.E. 2000. Whither antifoulings after TBT? NAV 2000 Proc. Intl. Conf. Ship and Shipping Research, 13th Congress paper 3.7, 19-22 September 2000, Venice, Italy.

ASTM (American Society for Testing and Materials). 1988. D121096 , Standard test method for fineness of dispersion of pigmentvehicle systems by Hegman-type Gauge. ASTM International, West Conshohocken. www.astm.org

ASTM (American Society for Testing and Materials). 2000. D71487 , Standard test method for evaluating degree of blistering of paints. ASTM International, West Conshohocken. www.astm.org

ASTM (American Society for Testing and Materials). 2001. D667701 , Standard test method for evaluating adhesion by Knife. ASTM International, West Conshohocken. www.astm.org

ASTM (American Society for Testing and Materials). 2004. D3623$78 \mathrm{a}$, Standard method for testing antifouling panels in shallow submergence. ASTM International, West Conshohocken. Www. astm.org

Callow M.E. 1996. Ship-fouling: The problem and method of control. Biodeterior. Abstr. 10: 411-421.

Cassé F., Swain G.W. 2006. The development of microfouling on four commercial antifouling coatings under static and dynamic immersion. Int. Biodeterior. Biodegradation 53: 179-185. https://doi.org/10.1016/j.ibiod.2006.02.008

Chambers L.D., Hellio C., Stokes K.R., et al. 2011. Investigation of Chondrus crispus as a potential source of new antifouling agents. Int. Biodeterior. Biodegradatio 65: 939-946. https://doi.org/10.1016/j.ibiod.2011.07.002

Champ MA. 2001. New IMO convention to control harmful antifouling systems on ships. Sea Technol. 42: 48-51.

Choi T.S., Kim J.H., Kim K.Y. 2001. Seasonal changes in the abundance of Ulva mats on a rocky intertidal zone of the southern coast of Korea. Algae 16: 337-341. 
Chung TJ. 1994. Oil and fats chemistry and coatings. J. Korean Oil Chem. Soc. 11: 17-38.

Del Amo B., Giúdice C., Sindoni O. 1989. High-build soluble matrix antifouling paints based on vinyl resin. Prog. Org. Coat. 17: $287-300$.

https://doi.org/10.1016/0033-0655(89)80030-5

Dobretsov S., Abed R.M.M., Teplitski M. 2013. Mini-review: Inhibition of biofouling by marine microorganisms. Biofouling 29: 423-441. https://doi.org/10.1080/08927014.2013.776042

Fletcher R.L. 1989. A bioassay technique using the marine fouling green alga Enteromorpha. Int. Biodeterioration, 25: 407-422. https://doi.org/10.1016/0265-3036(89)90067-5

Guardiola F.A., Cuesta A., Meseguer J., et al. 2012. Risks of using antifouling biocides in aquaculture. Int. J. Mol. Sci. 13: $1541-1560$

Hall W., Bushong S., Hall L., et al. 1988. Monitoring dissolved copper concentrations in Chesapeake Bay. Environ. Monit. Assess. 11: 33-42. https://doi.org/10.1007/BF00394510

Hattori T., Shizuri Y. 1996. A screening method for antifouling substances using spores of the fouling macroalga Ulva conglobata Kjellman. Fish. Sci. 62: 955-958. https://doi.org/10.2331/fishsci.62.955

Horiguchi T., Shiraishi H., Shimizu S., et al. 1997. Effects of triphenyltin chloride and five other organotin compounds on the development of imposex in the rock shell, Thais clavigera. Environ. Pollut. 95: 85-91. https://doi.org/10.1016/S0269-7491(96)00093-0

Hellio C., Berge J.P., Beaupoil C., et al. 2002. Screening of marine algal extracts for anti-settlement activities against microalgae and macroalgae. Biofouling. 18: 205-215. https://doi.org/10.1080/08927010290010137

Karlsson J., Eklund B. 2004. New biocide-free anti-fouling paints are toxic. Mar. Pollut. Bull. 49: 456-464 https://doi.org/10.1016/j.marpolbul.2004.02.034

Kim K.Y., Choi T.S., Kim J.H., et al. 2004. Physiological ecology and seasonality of Ulva pertusa on a temperate rocky shore. Phycologia 43: 483-492. https://doi.org/10.2216/i0031-8884-43-4-483.1

Kim N.S., Hong S.H., An J.G., et al. 2015. Distribution of butyltins and alternative antifouling biocides in sediments from shipping and shipbuilding areas in South Korea. Mar. Pollut. Bull. 95: 484-490. https://doi.org/10.1016/j.marpolbul.2015.03.010

Lejars M., Margaillan A., Bressy C. 2012. Fouling release coatings: a nontoxic alternative to biocidal antifouling coatings. Chem. Rev. 112: 4347-4390. https://doi.org/10.1021/cr200350v

Lin C.C., Yang C.H., Wu P.S., et al. 2011. Antimicrobial, antityrosinase and antioxidant activities of aqueous aromatic extracts from forty-eight selected herbs. J. Med. Plants Res. 5: 6203-6209.

Meinkoth N.A. 1990. Field guide to North American seashore creatures. The Audubon Society, Alfred A. Knopf, Inc., New York $1-813$

Mieszkin S., Callow M.E., Callow J.A. 2013. Interactions between microbial biofilms and marine fouling algae: a mini review. Biofouling. 29: 1097-1113. https://doi.org/10.1080/08927014.2013.828712

Muthukrishnan T., Govender A., Dobretsov S., et al. 2017. Evaluation reliability of counting bacteria using epifluorescence mi- croscopy. J. Mar. Sci. Eng. 5: 4. https///doi.org/10.3390/jmse5010004

Müller-Schwarze D., Houlihan P.W. 1991. Pheromonal activity of single castoreum constituents in beaver, Castor canadensis. J. Chem. Ecol. 17: 715-734.

https://doi.org/10.1007/BF00994195

Owen R., Knap A., Toaspern M., et al. 2001. Inhibition of coral photosynthesis by the antifouling herbicide Irgarol 1051. Mar. Pollut. Bull. 44: 623-632. https://doi.org/10.1016/S0025-326X(01)00303-4

Pettitt M.E., Henry S.L., Callow M.E., et al. 2004. Activity of commercial enzymes on settlement and adhesion of cypris larvae of the barnacle Balanus amphitrite, spores of the green alga Ulva linza, and the diatom Navicula perminuta. Biofouling. 20: 299-311. https://doi.org/10.1080/08927010400027068

Rascio V.J.D., Giudice C., Amo del B. 1988. Research and development of soluble matrix antifouling paints for ships, offshore platforms and power stations, a review. Corros. Rev. 8: 87-154. https://doi.org/10.1515/CORRREV.1988.8.1-2.87

Rascio V.J.D., Giudice C., Amo del B. 1990. High-build soluble matrix antifouling paints tested on raft and ship's bottom. Prog. Org. Coat. 18: 389-398. https://doi.org/10.1016/0033-0655(90)85016-Q

Rogers R.S., Hackman J.R., Mercer V., et al. 1999. Acetophenone tolerance, chemical adaptation, and residual bioreductive capacity of non-fermenting baker's yeast (Saccharomyces cerevisiae) during sequential reactor cycles. J. Ind. Microbiol. Biotechnol. 22: $108-114$. https://doi.org/10.1038/sj.jim.2900615

Schiff K., Brown J., Diehl D., et al. 2007. Extent and magnitude of copper contamination in marinas of the San Diego region, California, USA. Mar. Pollut. Bull. 54: 322-328. https://doi.org/10.1016/j.marpolbul.2006.10.013

Schultz M.P., Bendick J.A., Holm E.R., et al. 2011. Economic impact of biofouling on a naval surface ship. Biofouling 27: 87-98. https://doi.org/10.1080/08927014.2010.542809

Sidharthan M., Shin H.W., Joo J.H. 2004. Fouling coverage of a green tide alga, Ulva pertusa on some antifouling test surfaces exposed to Ayagin harbor waters, east coast of South Korea. J. Environ. Biol. 25: 39-43.

Sidharthan M., Jung S.M., Rai H.B., et al. 2006. A new antifouling hybrid CDP formulation with ethyl heptanoate: Evaluation of AF performance at Ayajin harbor, east coast of Korea. WSEAS Trans Syst. 5: 2354-2362.

Soroldoni S., Abreu F., Castro Í.B., et al. 2017. Are antifouling paint particles a continuous source of toxic chemicals to the marine environment? J. Hazard Mater 330: 76-82. https://doi.org/10.1016/j.jhazmat.2017.02.001

Stupak M.E., Garcia M.T., Perez M.C. 2003. Non-toxic alternative compounds for marine antifouling paints. Int. Biodeter Biodeg. 51: 49-52. https://doi.org/10.1016/S0964-8305(03)00035-0

Thouvenin M., Peron J.J., Guerin P., et al. 2002. Formulation and antifouling activity of marine paints: a study by a statistically based experiments plan. Prog. Org. Coat. 44: 85-92. https://doi.org/10.1016/S0300-9440(01)00247-8

Yebra D.M., Kiil S., Dam-Johansen K. 2004. Antifouling technology: past, present, and future steps towards efficient and environmentally friendly antifouling coatings. Prog. Org. Coat. 50: 75-104. https://doi.org/10.1016/j.porgcoat.2003.06.001 